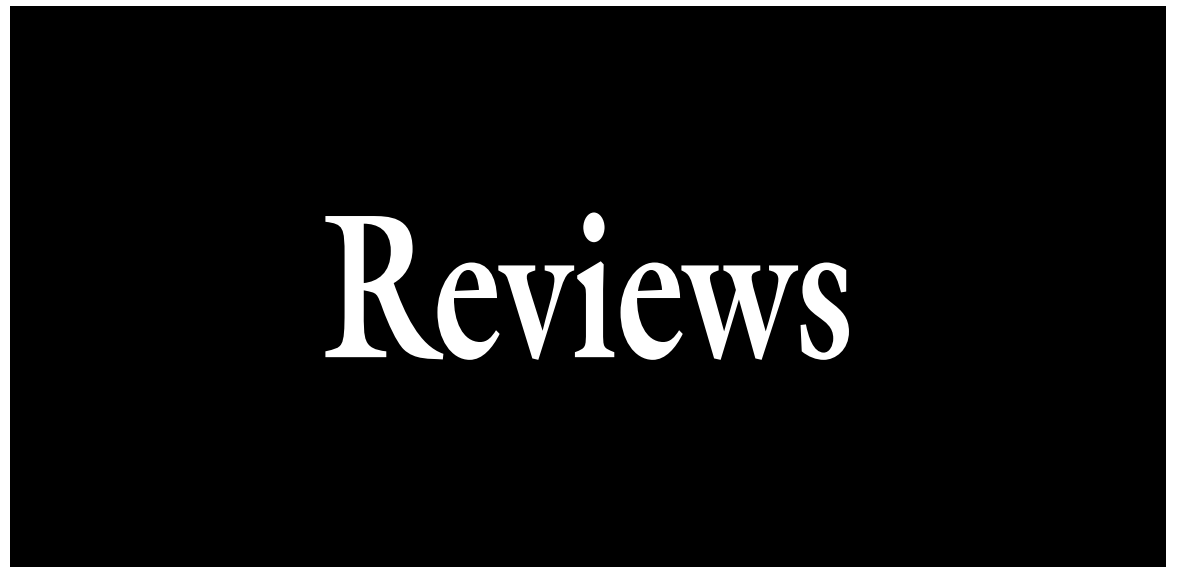

\section{A Review of Organic Lawn Care Practices and Policies in North America and the Implications of Lawn Plant Diversity and Insect Pest Management}

\author{
Sam Marshall ${ }^{1,4}$, David Orr ${ }^{1}$, Lucy Bradley ${ }^{2}$, \\ and Christopher Moorman ${ }^{3}$
}

\section{AdDITIONAL INDEX WORDs. turfgrass, landscape}

SUMMARY. There are $\approx \mathbf{4 0}$ million acres of turfgrass lawns throughout the United States, most of which are managed under chemical-intensive pest and fertilizer programs. "Organic lawn care" is being adopted more widely; however, unlike the formally defined policies and regulations that govern organic agriculture, the label organic lawn management has not been formally defined and is used to describe a variety of practices. Neighborhoods, cities, states, and provinces across North America are adopting policies regulating the use of pesticides and fertilizers in the landscape. In addition, a small but growing number of public institutions and individual consumers are successfully adopting alternative lawn care methods, including organic lawn care. Although perceived as environmentally friendly, the effects of organic management on insect diversity and pest management remain understudied. Organic lawn management may lead to increased lawn plant diversity, which in agroecosystems has enhanced ecological services provided by beneficial insect species. Effects of vegetative diversity on lawn pest management are less clear. Vegetative complexity and increased plant diversity in urban landscapes may enhance insect predator efficacy. The diversity of predatory insects varies between turfgrass varieties in response to prey populations. Mortality of insectivorous and granivorous ground beetles (Carabidae) while not directly impacted by pest management programs in turfgrass may be indirectly impacted by a reduction in the prevalence of plant species that provide alternative food resources. Previous studies have focused on herbivorous insects as well as predatory and parasitic insects that feed on them. Future studies should assess how lawn plant diversity resulting from organic management practices might impact insect communities in turfgrass.

A $s$ a result of the economic boom in the mid-20th century, the middle-class changed its way of life, increasing urban sprawl due to movement away from city centers (Robbins and Sharp, 2003a). From the mid-1950s to 1986, almost 69 million acres of natural habitat was converted to urban or suburban areas (Grey and Deneke, 1986). From 2000 to 2010 , urban (urban + regulations impose guidelines to maintain aesthetic property values, which often influence homeowners' needs to maintain lawns (Jenkins, 1994). However, arguably the most influential is the social pressure from neighbors who often ensure enforcement of lawn regulations, to which homeowners often conform (Byrne, 2005).

There are an estimated 40 million acres of nonnative grass lawns in the United States, covering almost $2 \%$ of land, making it the largest irrigated monoculture plant system in the country (Milesi et al., 2005; Tallamy, 2007). Lawns are often high-input systems, requiring significant amounts of time, monetary, and chemical investments to maintain aesthetic property value (Robbins et al., 2001). The prevalence of turf cover throughout the United States and a low tolerance for weed and insect pests coincides with an increase in the use of synthetic chemicals (Alumai et al., 2008). Conventional lawn management strategies are calendar-based applications of synthetic chemical inputs of fertilizers, herbicides, and insecticides (Alumai et al., 2008; Bormann et al., 1993) and have been associated with environmental pollution and human health risks [Robbins and Sharp, 2003a; U.S. Geological Survey (USGS), 1999]. As a result, strategies using integrated pest management (IPM) or "organic" practices have garnered increased attention as management alternatives (Alumai et al., 2008).

Some individual consumers and public institutions have adopted alternative lawn management strategies, which have been promoted as a way to prevent potential negative environmental consequences of the overuse or misuse of pesticides (Henderson et al., 1998). The growing interest in lawn management alternatives has led to changes in public policies which ban the use of cosmetic pesticide applications and favor the adoption of lawn alternatives (Vickers, 2006), including organically managed green spaces (Alumai et al., 2008).

Although organic management programs are offered as an alternative to traditional lawn care, their impact on arthropod diversity and pest management is poorly understood. A goal of commercial IPM or organic management is to enhance the overall aesthetic quality of lawns, which 
includes suppression of pests that invade turf (Alumai et al., 2008). Since little is known about the effects of organic lawn management on arthropod communities, this article reviews literature pertinent to organic lawn care, highlighting studies that have assessed the effects of turf variety and management practices on insect communities. To put this information into context, the article begins with an assessment of what organic lawn management means and the history of public policy regarding its implementation in North America.

\section{Defining Organic Lawn Management}

The U.S. Department of Agriculture (USDA) defines organic agriculture as "... an ecological production management system that promotes and enhances biodiversity, biological cycles, and soil biological activity. It is based on minimal use of off-farm inputs and on management practices that restore, maintain, and enhance ecological harmony" (USDA, 1995). The USDA National Organic Program (NOP) administers and publishes organic regulations with input from the public and the National Organic Standards Board. Before being certified as organic, farms must undergo a 3-year transition period in which organic production practices are followed, and documentation must be provided that no unapproved products or practices were used in the production system. Producers must then submit an application and fees to a USDA-accredited certifying agent (state departments of agriculture or private organizations). After an on-site inspection and review of the application indicate the producer is in compliance with USDA organic regulations, the certifying agent will issue an organic certificate. Producers are required to provide annual updates to the certifying agent, who performs an annual

\footnotetext{
${ }^{1}$ Department of Entomology, North Carolina State University, 1110D Grinnells Hall, Raleigh, NC 27695

${ }^{2}$ Department of Horticultural Science, North Carolina State University, 128 Kilgore Hall, Raleigh, NC 27695

${ }^{3}$ Department of Forestry and Environmental Resources, North Carolina State University, Box 7646 , Turner House, Raleigh, NC 27695

${ }^{4}$ Corresponding author. E-mail: wsmarsh2@ncsu.
} edu inspection to ensure USDA regulations are still being met.

Except for cases where turf is grown commercially for sod or seed production, lawns are not agricultural commodities and so their management is not regulated other than by local municipal and homeowner association aesthetic rules. Because there has been no groundswell of support for consistent definitions of organic lawn management and accompanying regulations like for agricultural commodities, there is no national definition or regulation of organic lawn care. This article refers to organic lawn management with the understanding that there are many varying definitions.

\section{Relevant Public Policy in North America}

Grassroots organizations throughout North America are pushing institutions as well as local and regional governments to restrict the use of pesticides and adopt organic or similar management policies for public spaces. These changes are being made primarily because of perceived public health concerns, even though the consequences of these policies may not yet be fully understood (e.g., labor requirements, pest management). The following section reviews these policy changes to put the discussion of organic lawn management into context.

\section{Public Policies in Canada}

In 1991, the Montreal suburb of Hudson, QC was the first municipality to adopt a bylaw prohibiting the nonessential use of pesticide applications in public and private properties (Pralle, 2006a; Robbins and Sharp, 2003b). In Canada, national and provincial governments oversee the types and safety of chemicals that can be sold (Pralle, 2006a). While this power was not explicitly stated for local municipalities, they did have the power to adopt bylaws that protected the health and well-being of the general public (Pralle, 2006a). In 1992, Spraytech (Calgary, AB) and Chemlawn (Memphis, TN) filed suit against Hudson, QC, claiming that municipalities did not have the right to impose bans on chemicals which had been approved for use by national and provincial governments (Pralle, 2006a). The two companies brought the case to Quebec's Superior Court, where the decision of Hudson to ban nonessential applications of pesticides was upheld (Pralle, 2006a). Eventually, the case went to the Canadian Supreme Court, and in 2001 it upheld Hudson's right to ban nonessential use of chemicals (Pralle, 2006a). It also extended its decision, and included the right of all local municipalities throughout Canada to adopt bylaws that banned cosmetic chemical applications in public and privately owned green spaces (Pralle, 2006a). By 2005 , there were 70 municipal bylaws which banned the nonessential use of pesticides in Canada (Pralle, 2006a).

In 2003, the Canadian province of Quebec adopted a pesticides management code in an attempt to mitigate deleterious effects from the overuse of pesticides in publicly managed green spaces. The code was revised several years later, and in 2006 extended its guidelines to include commercial as well as privately managed lawns in urban areas (Province of Quebec, 2012). Guidelines of the code mandate that all applicators, whether for commercial or private (residential) use, file for an application permit stating just cause and purpose for application of pesticides (Province of Quebec, 2012). Following application of pesticides, signs must be posted notifying the public that pesticides have been applied with the maximum allowable reentry period, depending on the type of chemical that has been applied (Province of Quebec, 2012).

In 2004, the city of Regina in the Canadian province of Saskatchewan adopted the cosmetic pesticide policy,

\begin{tabular}{llll}
\hline $\begin{array}{l}\text { Units } \\
\begin{array}{l}\text { To convert U.S. to SI, } \\
\text { multiply by }\end{array}\end{array}$ & U.S. unit & SI unit & $\begin{array}{l}\text { To convert SI to U.S., } \\
\text { multiply by }\end{array}$ \\
\hline 0.4047 & acre $(\mathrm{s})$ & ha & 2.4711 \\
3.7854 & gal & $\mathrm{L}$ & 0.2642 \\
40.7458 & gal $/ \mathrm{ft}^{2}$ & $\mathrm{~L} \cdot \mathrm{m}^{-2}$ & 0.0245 \\
25.4 & inch $(\mathrm{es})$ & $\mathrm{mm}$ & 0.0394
\end{tabular}


which prevents the use of cosmetic pesticide applications in publically managed green spaces in favor of an IPM program (Hjertaas, 2007). Unlike the other Canadian provinces, Saskatchewan does not have bylaws or restrictions on cosmetic pesticide use (Hjertaas, 2007).

Ontario, Canada adopted a ban on the nonessential use of chemical pesticides on lawns in 2008 (Suzuki and Moola, 2009). The Ontario Pesticides Act provides legal and regulatory policies that require all commercial pesticide applicators receive proper training in the application and handling of pesticides (Province of Ontario, 2009). The cosmetic pesticides ban was added to the Pesticides Act in Apr. 2009 and establishes a clear set of guidelines that commercial pesticide applicators must follow to reduce the nonessential use of pesticides throughout public, residential, and privately owned areas (Province of Ontario, 2009). The policy is mandated throughout the entire province of Ontario, but does not include consumer-managed lawns (Province of Ontario, 2009).

Alberta mandated a policy similar to Ontario's in 2008 and in 2009, New Brunswick and Prince Edward Island followed suit by adopting pesticide use restrictions in publicly managed green spaces (Christie, 2010). Most recently, Nova Scotia adopted the Nonessential Pesticides Control Act, which restricts the sale and use of nonessential pesticides for lawn care, including residential and publically managed green spaces (Government of Nova Scotia, 2011). The province of Manitoba is currently considering similar bans on cosmetic pesticide applications throughout the entire province (Winnipeg Free Press, 2012). As of 2010, almost $180 \mathrm{mu}^{-}$ nicipalities throughout most Canadian provinces have adopted similar bans on pesticide use for cosmetic purposes (Christie, 2010).

\section{Public Policies in the United States}

In the United States, local and state regulations have focused on resident notification by lawn care companies when pesticides were applied (Pralle, 2006b). In 1985, Casey, WI enacted a pesticide ordinance that required permits for pesticide use and placed bans on aerial applications of pesticides (Pralle, 2006b). In 1991, the ordinance was challenged by farmers, ranchers, and the timber industry, claiming that the Federal Insecticide, Fungicide, and Rodenticide Act (FIFRA) preempted local regulations. However, the U.S. Supreme Court ruled that FIFRA did not prevent the regulation of pesticides by local governments and upheld decisions by municipalities to pass pesticide bans (Pralle, 2006b). The chemical industry lobbied successfully at the federal level for state preemption laws, which meant that state laws could override stricter pesticide policies adopted at the local level (Pralle, 2006b).

Local governments, as a result of state preemption laws, were therefore slower to adopt pesticide-use regulations because of legal conflict with state laws (Pralle, 2006b). One of the first nonessential pesticide bans came in 2009, as a response to public and environmental health concerns of the overuse of pesticides in Chicago, IL city parks. The Chicago Park District partnered with the Safer Pest Control Project to "naturally" manage public green spaces in the greater Chicago area (Chicago Park District, 2011). The focus of the project was to eliminate the nonessential use of synthetic pesticides and fertilizers, to mitigate public health concerns with the overuse of chemicals (Chicago Park District, 2011).

In King County, WA, 102 of the 189 public green spaces are pesticide free, and 87 are pesticide reduced (Enumclaw Courier-Herald, 2012). Ogunquit, Rockport, and several other communities throughout Maine currently prohibit chemical-intensive landscaping in public areas (Beyond Pesticides, 2010).

IPM practices and policies have been adopted in publicly managed green spaces throughout the United States. In Mar. 1999, Carrboro, NC, adopted an IPM program for all publically managed properties within the town. The plan was adopted as a result of the growing concern of the public health risks involved with cosmetic applications of chemical pesticides to treat public green spaces (Town of Carrboro, Department of Public Works, 1999). The program mandates that each department within the town government have a written IPM plan for the management of municipal property and is written with and reviewed by the IPM coordinator (Town of Carrboro, Department of Public Works, 1999). The town also adopted the Least Toxic IPM Manual, which provides municipal land managers a protocol for developing and using preventative control measures for pests, using the least toxic form of chemical available (Town of Carrboro, Department of Public Works, 1999). To date, the IPM policy for Carrboro only applies to publicly managed green spaces, and is not mandatory for residents living within the town limits (Town of Carrboro, Department of Public Works, 1999).

Voorhees, NJ, requires all public properties and township parks to be managed under an IPM program and requires postage of signs in areas that have been treated with pesticides (Beyond Pesticides, 2008). New Jersey is one of 21 states that require homeowners to display postings in lawns where chemicals have been used to treat turf; it is also one of 14 states that require state agencies and individual companies to establish a registry for people to sign up for prior notification when adjacent properties are being treated with chemical sprays (Beyond Pesticides, 2012a). To date, over 30 communities in New Jersey have adopted IPM strategies or have banned cosmetic pesticide use altogether (Bernardsville News, 2012).

The Cuyahoga County Council in Ohio recently approved a policy that limits the use of chemical pesticides on the public green spaces in an attempt to reduce nonessential pesticide applications (Beyond Pesticides, $2012 \mathrm{~b})$. The policy promotes IPM strategies, emphasizing scouting and proper identification of pest problems, and the judicious use of chemical applications, only when pest pressure poses an immediate threat to public health and when other alternatives to pest control are not available (City Council of Cuyahoga County, OH, 2011). The restrictions also require that advanced public notice be given when chemical pesticides are used in public spaces, and enforces the maximum reentry period following applications (City Council of Cuyahoga County, OH, 2011).

In 2007 , as a response to public and environmental health concerns of the overuse of pesticides in city parks, Greenbelt, MD, assembled an advisory committee to conduct a 2 -year study that assessed the monetary cost of 
pesticide usage within the city limits (Greenbelt City Council, 2012). Based on their findings, the committee determined that nonessential applications of fertilizers and pesticides were expensive and proposed to eliminate the cosmetic applications of pesticides in publicly managed green spaces and adopt more sustainable land management practices to alleviate monetary costs as well as public health concerns (Greenbelt City Council, 2012). In 2012, Greenbelt, MD adopted the Sustainable Land Care Policy, which bans all cosmetic uses of pesticides in an attempt to phase out the unnecessary use of chemicals for turf treatment (Riddle, 2011). Under the law, professional contractors and landscapers must operate under an IPM or completely organic strategy for maintaining turf. Some of these strategies include using plant varieties resistant to pest pressure, and using manual, mechanical, and biological controls to deal with pest issues, such as weeds and insects (Riddle, 2011). IPM programs selectively use chemical controls as a final option, when pests escape other forms of control [U.S. Environmental Protection Agency (USEPA), 2012].

In various states across the country, public schools are adopting IPM programs to manage school grounds. In 2004, New Jersey implemented a statewide New Jersey School IPM Program, which requires that all schools in the state manage their grounds under IPM practices and mandates that a minimum of 72 -h advanced notice be given to parents when pesticide applications are made to school grounds (New Jersey Department of Environmental Protection, 2004). Since then, California, Texas, North Carolina, and other states have adopted IPM programs for managing school grounds (U.S. Environmental Protection Agency, n.d.).

In addition to outright bans on pesticide use or implementing IPM programs, some municipalities have adopted organic management policies for publicly managed areas. In 2001, the town of Marblehead, ME, adopted the organic land management policy for turfgrass, which was the first implementation of organic policies to reduce and eventually eliminate pesticide use on townowned land (Town of Marblehead, ME, 2001). An organic pest management advisory board was assembled to prioritize the use of cultural, mechanical, and manual controls to reduce pest pressure. The advisory board does allow use of chemical controls in the event of public emergencies (Town of Marblehead, ME, 2001). The policy was disputed by professional landscapers as well as the school board, who claimed that implementation of these practices would be more expensive and not as cost effective as a balanced approach for managing turf (Capone, 2002).

Camden, ME, passed the Pest Management Policy, which emphasizes the use of organic practices to manage public green spaces (Town of Camden, ME, 2008). The ordinance prevents the use of pesticides on publicly managed grounds, and operates under organic practices, using cultural, mechanical, and products approved by the Organic Materials Review Institute (OMRI) to deal with pest issues (Town of Camden, ME, 2008). The Healthy Turf and Landscape Policy, adopted by the Village of New Paltz, NY, prohibits the application of pesticides for aesthetic purposes on municipal properties and emphasizes the use of organic and cultural management practices as preventative approaches to offsetting pest problems in turfgrass (Village of New Paltz Board of Trustees, 2008). Similarly, the community of Wellfleet, MA limited the amount and types of pesticides used for managing their green spaces (Bragg, 2012) and recently adopted the Municipal Organic Land Management Policy, which prohibits the use of synthetic fertilizers on public green spaces and other municipal properties (Bragg, 2012).

In Durango, CO, under the citizen initiative petition provision of the Durango City Charter (City of Durango, CO, 1986), residents proposed an Organic Land Management Program, which would reduce and eventually eliminate the use of chemical fertilizers and pesticides throughout all city parks (City of Durango, $\mathrm{CO}, 2012)$. Further, the program planned to implement organic turf management methods such as mechanical and manual strategies to deal with pests (City of Durango, CO, 2012), and only allows the use of pesticides in a case of public health emergency, when other methods of control are unsuccessful (City of Durango, CO, 2012).

Opponents to the ordinance estimated substantial increases in cost for the organic management of green spaces, due to an increase in cost of organic fertilizer as well as an increase in labor costs from manual removal of weeds (Chamberlin, 2012). Under the charter, ordinances proposed by citizen petitions cannot exceed available monetary funds of the city (City of Durango, CO, 1986). The proposal also allowed any individual citizen the right to sue the city if there was failure to comply with the regulations within the ordinance (City of Durango, CO, 2012). On 21 Aug. the proposal was vetoed by the city council (Boardman, 2012). However, in early Sept. 2012 the city council reached a compromise with advocates of the citizen group and voted to develop and evaluate a program that minimized pesticide use and would slowly phase in organic management practices, rather than completely switch from conventional to organic management (Boardman, 2012). As an initial step to adopting organic management strategies, the city council allotted a budget of $\$ 36,000$ to hire a consultant to develop and estimate the cost of implementation of an organic program for all city parks throughout Durango (Boardman, 2012).

Grassroots movements throughout North America are pushing local governments to modify their land management policies to address perceived public health concerns over pesticide applications. If this trend continues, it will become more important to understand the consequences of these new policies.

\section{Organic Lawn Management Practices}

Because organic management in lawns does not have any legal or regulatory guidelines, a variety of practices have either been suggested by authors or used by practitioners. Although not supported by experimental studies, Tukey (2007) suggests using materials for lawn management that are certified by OMRI as acceptable for organic agriculture including fertilizers such as organic composts or teas, and commercially available products to treat turf pests. An extreme approach to creating an "organic lawn" is to replace turfgrass with a "no-mow" herbaceous groundcover alternative that may not require the 
types of chemical and physical inputs associated with traditional turf management (Tukey 2007).

Life cycle assessments by Morris and Bagby (2008) have suggested that "organic-centered" lawn management reduces pesticide exposure and pollution, and minimizes water usage and runoff. Morris and Bagby (2008) also found that turf managed with an organic-centered approach required $\approx 8.1 \mathrm{~L} \cdot \mathrm{m}^{-2}$ of water for irrigation annually per square meter of lawn, as opposed to $903 \mathrm{~L} \cdot \mathrm{m}^{-2}$ in a conventionally managed lawn. The direct causes for the reduction in irrigation were not evaluated. However, studies in organic agricultural systems have shown that an increase in soil biomass increases water retention, which ultimately leads to a higher tolerance in drought conditions (Pimental et al., 2005). Increasing organic matter in lawn soils may lower the risk for pest damage by supporting healthier root systems, so that turfgrass has a higher tolerance for pest pressure and damage, and a reduced need for pesticides (Bruneau, 1997). In a comparison of management programs, Alumai et al. (2008) found that organic management programs resulted in fewer herbicide and insecticide treatments than conventional programs, and thus a reduction in annual maintenance costs, with comparable aesthetic qualities to a conventionally managed system.

Bruneau (1997) suggests four practices for organic management of insect pests: 1) prevent insect damage by nurturing a healthy lawn to better tolerate pest damage; 2) reduce thatch layer to limit favorable conditions for insect habitation; 3 ) properly identify pest insects vs. nonpests; 4) spot treatment with pesticides (e.g., treating only when and where it is needed) instead of broadcast applications. To help with the latter two practices, Bruneau (1997) presents identification and scouting information for major turfgrass pests.

\section{Organic Lawns on University Campuses}

In Mar. 2008, Harvard University converted a 1 -acre plot of conventionally managed turfgrass into organic lawn (Raver, 2009). The objective was to eliminate use of synthetic chemicals used to manage turf and compare the soil quality, biological activity, and nutrient contents, and overall health of the organically managed turf vs. conventionally managed turfgrass. After 8 months, the organically managed test plot had more nutrient cycling and supported more root growth, higher nitrogen levels, and reduced need for irrigation than control plots under conventional management practices (Raver, 2009). The internal landscape department maintains $\approx 65 \%$ (52 acres) of Harvard properties, which have been managed organically since 2008; however, landscape managers hope to convert all 80 acres of Harvard University to organic practices (Raver, 2009; W. Carbone, personal communication). As a result of the switch from conventional to organic landscape practices the university noted a first-year savings of $\approx 2$ million gallons of water from reduced irrigation, and $\$ 45,000$ in landscape waste removal fees from on-campus composting (Raver, 2009).

In 2011, The University of Colorado in Boulder began the first full year of implementation of organic compost tea applications through their irrigation system as a way to increase soil nutrients and soil microbial populations, with the intentions of minimizing and eventually eliminating the need for synthetic turf inputs (Tukey, 2012a; D. Inglis, personal communication). Any differences in annual costs associated with conventional vs. organic programs will be examined by comparing results from soil bioassay tests, including biological soil fauna composition pre- and postimplementation of the organic tea applications (D. Inglis, personal communication).

In 2009, Swarthmore College started managing $\approx 5$ acres of their grounds under organic practices to compare the differences, if any, with plots under conventional management strategies (Smith, 2011). Root growth increased from $\approx 3.5$ to 5.5 inches on average since converting to organic methods; however, weed pressure and visual greenness is not noticeably different between conventional and organically managed plots (N. Selby, personal communication). While synthetic fertilizer and pesticide expense has been eliminated, it has been replaced with compost screening, organic fertilizer and seed purchases, and staff training to monitor soil biology and as a result, there have been no savings in cost since converting to organically managed turf (N. Selby, personal communication).

Since Mar. 2012, the University of Arizona managed 12 acres of open grass in their central mall under organic practices, which includes applications of aerated compost tea and the elimination of pesticides and fertilizer applications (M. Anderson, personal communication). Visual comparisons of organic and conventionally managed areas on Arizona's campus have not yielded any notable differences in the quality of turf between the test plots; however, they are currently awaiting soil analysis results to compare the soil biotic composition between the organic and conventionally managed areas (M. Anderson, personal communication; Tukey, 2012b). Thus far, widespread adoption has been prevented due mainly to high labor expenditures and lack of adequate equipment required to maintain the 12-acre plot; however, they are seeking alternative, more efficient delivery methods similar to the one at the University of Colorado, Boulder, which uses the irrigation system for applications of compost tea (M. Anderson, personal communication).

\section{Organic Practices in Golf Courses}

There are several examples of golf courses taking organic approaches to managing their greens. A golf course in Lubbock, TX, recently converted $80 \%$ to $90 \%$ of its fairways and greens to organic care (Morris, 2011). For more than 50 years prior, the land that the course now occupies was under intensive management as a cotton farm and soil quality was a major concern for the owners. Over a period of 5 years, the course converted 270 acres of intensively managed greens to lowinput practices. The application of compost teas and other organic soil amendments resulted in using almost $1 / 4$ million fewer gallons of water used per day than other courses under conventional management, despite being 120 acres larger (Morris, 2011).

The Vineyard Golf Club in Martha's Vineyard, MA thought to be the only completely organic golf course in the country, uses no synthetic pesticides or fertilizers to manage the greens, fairways, and other green spaces throughout the grounds 
(Pennington, 2010). Before construction of the golf course, surrounding subdivisions expressed concern over the potential hazards of using synthetically produced chemicals to control the greens (Pennington, 2010). This ultimately resulted in the Martha's Vineyard Commission allowing the course to be constructed under the stipulation that no synthetically produced chemicals could be used to manage the grounds (Pennington, 2010).

\section{Arthropod Management in Turfgrass Systems}

It is not yet clear what the effects of organic lawn management on economics, water management, soil quality, aesthetics, and weed management, but a few institutions are currently evaluating organic practices before full-scale implementation. However, none are evaluating the effects of these practices on insect pest management, even though there is a concern that organically managed lawns may have more pest problems (Chamberlin, 2012).

Plant management in and AROUND TURF. Organically managed lawns may be expected to have higher plant species diversity, which has been shown to increase arthropod populations in other systems (Andow, 1991). While arthropods have been studied in turfgrass systems, no studies have directly evaluated the effects of increased lawn plant species diversity on their populations.

Plant diversity has been evaluated in agricultural systems, and has been shown to enhance ecological services provided by beneficial arthropods (Marino and Landis, 1996; Menalled et al., 1999). Also studied are the effects of increasingly complex environments that increase habitat suitability for beneficial arthropods by providing alternative food resources such as nectar and pollen (Landis et al., 2000). Theis et al. (2003) demonstrated that the amount of noncrop vegetation in agricultural landscapes was directly correlated with parasitism of agricultural pests, and concluded that landscapes with more than $20 \%$ of noncrop vegetation had meaningful reductions in insect herbivore populations and damage to crop plants. As habitat complexity and surrounding noncrop vegetation increases, the stability of that vegetation community likely will increase (Theis et al., 2003). An increase in vegetative complexity may offer sources of refuge, alternative food sources, greater variability in microclimates, or increase the ability to locate prey effectively, and the ability to avoid intraguild predation (Landis et al., 2000; Langellotto and Denno, 2004).

Habitat complexity has also been studied in urban systems (Raupp et al., 2010; Shrewsbury and Raupp, 2000, 2006). Urban systems often involve less frequently disturbed perennial plantings and have higher plant diversity than natural areas (Raupp et al., 2010). As a result, urban areas may experience fewer pest outbreaks due to an increase in food web stability (Raupp et al., 2010; Shrewsbury and Raupp, 2000, 2006). Shrewsbury and Raupp (2006) demonstrated lower populations of azalea lace bug (Corythuca sp.) pests in habitats with more complex vegetative surroundings. Vegetatively complex habitats support greater populations of endemic natural enemies and generalist predators, as well as alternative prey food sources (Shrewsbury and Raupp, 2006).

In golf courses, Frank and Shrewsbury (2004) showed that conservation strips of different flowering plants near turfgrass fairways increased the diversity of both predatory and parasitic beneficial insects. This study demonstrated an increase in predation of black cutworm (Agrotis ipsilon) when conservation strips were planted near fairways; however, increase in predation was not necessarily correlated with an increase in predator abundance suggesting that abundance alone might not be an accurate measurement for pest control in turfgrass (Frank and Shrewsbury, 2004).

Similarly, Braman et al. (2002) evaluated the potential for wildflower borders to increase abundance and impact of beneficial arthropods in the landscape and to determine whether natural enemies and pest-resistant turfgrass varieties could be compatible in the control of japanese beetle grub (Popillia japonica) and fall armyworm (Spodoptera frugiperda). This study demonstrated greater abundance of some predatory arthropods such as big-eyed bugs (Geocorus sp.) and foliar-dwelling spiders (Aranae) in turfgrass plots surrounded by flowering plant borders than in those surrounded by mulch. Although abundance and diversity of these predators was influenced by increased plant diversity, there was no difference in predation rates of fall armyworm and japanese beetle grub across treatment types (Braman et al., 2002). Also demonstrated was an increase in the occurrence of beneficial parasitic wasps (Hymenoptera) in turfgrass plots surrounded by diverse flower mixes; however, their efficacy for insect pest control was not evaluated (Braman et al., 2002).

Natural CONTROL FROM PARASITOIDS AND PREDATORS. Pedigo and Rice (2006) define natural control as “... the suppression of pest populations by naturally occurring biotic and abiotic factors." Turfgrass habitats have the ability to support diverse arthropod communities including herbivores, predators, and detritivores (Potter, 1993). A review by Potter and Braman (1991) highlighted common pests in turfgrass and their management, including the use of IPM programs and biological control agents. They suggested that high-intensity management systems may experience more frequent pest outbreaks because of repeated insecticide applications, which have been shown to negatively affect natural enemies important in IPM and biological control (Potter and Braman, 1991). Low-intensity turfgrass systems appear to be more stable due to natural enemy predation and parasitism, and as a result, experience fewer pest outbreaks (Potter and Braman, 1991).

Braman and Pendley (1993) catalogued ground-dwelling arthropod fauna in centipedegrass (Ermochloa ophiuroides) under high- and lowintensity management conditions. Highintensity systems were based on regular applications of chemical insecticides, while low-intensity sites received no treatment for the 2-year duration of the study. They concluded that different types of arthropods responded differently to management practices. For instance, ground beetles and ants (Formicidae) were found in greater numbers in the low intensity sites, presumably because of the greater number of alternative herbaceous resources available (Braman and Pendley, 1993). In the high-intensity plot, parasitic wasps, and spiders were adversely affected immediately following insecticidal applications, while rove beetle (Staphylinidae) populations were positively impacted due to the increase in decaying vegetation (Braman and Pendley, 1993). The 
occurrence and abundance of parasitic wasps in turfgrass has also been documented (Braman and Pendley, 1993; Braman et al., 2002; Held, 2005; Joseph and Braman, 2009, 2011). Joseph and Braman (2009) documented that turfgrass variety influenced which types of parasitic wasp were present, likely due to the host specificity of parasitic wasps and relative abundance of primary hosts. Although this study indicated an abundant and diversity of parasitic wasps, their efficacy for managing insect pest populations in turfgrass was not evaluated.

To determine how direct impacts of management programs might impact ground beetles, Blubaugh et al. (2011) compared beetle diversity across four lawn management programs: 1) high-input, calendar-based consumer program, based on recommendations from a professional lawn care company, 2) an IPM program, 3) an organically managed program, and 4) a no-input program (Caceres et al., 2010). Populations of ground beetles were monitored and the species were categorized as either predatory, granivorous, or omnivorous (Blubaugh et al., 2011). Ground beetle communities were not directly impacted by management regime. Consumer and IPM programs had fewer ground beetle populations than no-input systems. The most prevalent weed species present [white clover (Trifolium repens), dandelion (Taraxacum officinale), and crabgrass (Digitaria ischaemum)] did have a slightly positive impact on weed-feeding beetles, indicating that a reduction of weed species through the use of herbicidal treatments might have a negative, indirect impact on granivorous species of ground beetle communities (Blubaugh et al., 2011).

Joseph and Braman (2009) compared natural enemies and their potential prey abundance in four common warm-season turfgrass varieties and concluded that turfgrass type influenced relative abundance of herbivorous and predatory hemipterans, likely due to the availability of preferred, more nutritious primary and non-preferred, but abundant alternative food resources. Among all types of arthropods, species evenness and diversity were significantly impacted by turfgrass variety (Joseph and Braman, 2009). These authors also reported that relative population density of predatory bugs (Geocoridae and Miridae) was positively impacted by weed density, noting the tendency of these groups to switch feeding habits based on prey availability (Joseph and Braman 2009). This study suggested how knowledge of turfgrass variety and potential resistance to pests may enhance beneficial arthropod populations for more effective pest control in turfgrass systems (Joseph and Braman, 2009).

It is worth noting that overall plant diversity was not assessed in this study, so conclusions could not be made as to how the diversity of plant communities within lawns impact arthropod abundance and diversity.

INSECT PEST RESISTANT TURFGRASS VARIETIES. Warm-season turfgrass varieties have been evaluated for their resistance to a variety of phytophagous pest insects (Quisenberry, 1990; Reinert et al., 2004; Shortman et al., 2002). Employing resistant turfgrass varieties may help reduce damage from insect pests, which could lead to a reduction in the need for pesticides (Braman et al., 2000a; Quisenberry, 1990; Reinert et al., 2004).

The efficacy of pest management in resistant turfgrass varieties has been evaluated as a stand-alone strategy for insect pest management (Braman et al., 2000a). Laboratory studies demonstrated that two varieties of commercially available zoysiagrass (Zoysia sp.) had high levels of antibiosis on fall armyworm larvae (Braman et al., 2000a), and two commercially available varieties of turfgrass had moderate resistance to mole cricket (Gryllidae) damage (Braman et al., 2000b).

Anderson et al. (2006) evaluated the resistance of several commercially available warm-season turfgrass varieties to multiple chinch bug species (Blissus sp.). This study demonstrated that 'Floratum' st. augustinegrass (Stenotaphrum secundatum) was highly resistant to southern chinch bug (B. insularis) whereas 'Raleigh' and 'Amerishade' varieties were only moderately resistant to southern chinch bug (Anderson et al., 2006). Demonstrated further was a high level of resistance of 'Floratum', 'Amerishade', and 'Raleigh' varieties to the chinch bug species B. occidus (Anderson et al. 2006). Results of this study suggested that selection of turfgrass varieties with resistance to multiple species of phytophagous insect pests should be used to mitigate pest damage (Anderson et al., 2006).
The compatibility of resistant turfgrass varieties with beneficial arthropods for control of insect pest populations in turfgrass has also been evaluated in field studies on predators (Braman et al., 2003) and parasitic wasps (Braman et al., 2004). Braman et al. (2003) evaluated the compatibility of resistant turfgrass varieties with predatory big-eyed bugs (Geocoris uliginosis). This study demonstrated that resistant zoysiagrass alone kept fall armyworm populations low and the addition of big-eyed bugs had no effect on pest numbers (Braman et al., 2003). In turfgrass varieties susceptible to fall armyworm, this same study demonstrated no effect of predators on effectively managing pest populations (Braman et al., 2003).

Braman et al. (2004) evaluated the compatibility of resistant turfgrass varieties with parasitic wasps of fall armyworm. This study demonstrated a lower percentage of parasitized fall armyworm in turfgrass varieties highly resistant to fall armyworm (Braman et al., 2004). Although percent parasitism was decreased with increased levels of turfgrass resistance this study demonstrated higher levels of parasitism in bermudagrass (Cynodon sp.) varieties with moderate levels resistance (Braman et al., 2004).

\section{Discussion}

Various interpretations of organic lawn care exist with no clear consensus of what exactly constitutes organic lawn management. Organic lawn care might be considered a laissezfaire approach that lets weeds and turfgrass cohabitate the same area, or it could be viewed as active management that uses only OMRI-approved products. The common theme in all organic lawn management programs to date is the desire to avoid use of synthetic chemicals, especially pesticides. Because lawns are not consumed, there is no federal agency responsible for their regulation, and there are no marketing advocates demanding consistency in definition or regulation. As a result, it is unlikely there will be a consensus any time soon on what, specifically, constitutes organic lawn management.

Interest in organic lawn management throughout North America is growing, and a number of entities 
have adopted pesticide restrictions, bans, or organic management practices in public spaces. Legal disputes between advocacy groups in some of these cases have progressed all the way to the federal Supreme Courts of both the United States and Canada.

Despite the pressures to reduce chemical inputs and reduce water consumption, high demands on the aesthetic quality of turfgrass continue to face the turfgrass industry. (Held and Potter, 2012). Because the economic and environmental consequences of implementing organic lawn management are not clear, some of the institutions that are implementing organic practices are conducting their own assessments before fullscale implementation. New insight into pest biology and the breeding of pest-resistant turfgrass varieties to mitigate pest damage have emerged as a way to maintain high aesthetic quality of lawns, reduce pests, as well as chemical inputs. Also studied is the compatibility of resistant varieties with controls from natural enemies, and how increased plant diversity surrounding turfgrass may sustain these natural controls.

The influence of pest-resistant turfgrass varieties has been evaluated for possible use as an effective IPM strategy in turfgrass. Greenhouse and field trials suggest that breeding resistant varieties of turfgrasses could be effective as a stand-alone strategy for reducing pest pressure from some pests (Held and Potter, 2012). Highly resistant turfgrass varieties may work as an effective deterrent in some instances (Anderson et al., 2006), but may not be compatible with controls from natural enemies; however, moderately resistant varieties have shown potential use with natural enemies (Braman et al., 2004).

No studies have examined directly the effects of expected increased lawn plant species diversity in organic lawns on arthropod populations. Studies from agricultural research indicate that increasing vegetative diversity increases beneficial arthropod effectiveness in suppressing pest populations (Theis et al., 2003). In turfgrass systems, the influences of surrounding vegetative diversity on diversity of predatory and parasitic arthropods have been evaluated. In some instances, an increase in vegetative diversity surrounding turfgrass may enhance pest control from natural enemies (Frank and Shrewsbury, 2004); however, this may not always be the case (Braman et al., 2002). To date, however, no studies have evaluated the effects of the supposed increase in lawn plant diversity from organic lawn management on beneficial arthropod populations, which should be addressed as part of an effort to understand the consequences of larger-scale adoption of organic lawn management.

\section{Literature cited}

Alumai, A., S.O. Salminen, D.S. Richmond, J. Cardina, and P. Grewal. 2008. Comparative evaluation of aesthetic, biological, and economic effectiveness of different lawn management programs. Urban Ecosyst. 12:127-144.

Anderson, W.G., T.M. Heng-moss, and F.P. Baxendale. 2006. Evaluation of cooland warm-season grasses for resistance to multiple chinch bug (Hemiptera: Blissidae) species. J. Econ. Entomol. 99:203-211.

Andow, D.A. 1991. Vegetational diversity and arthropod population response. Annu. Rev. Entomol. 36:561-596.

Bernardsville News. 2012. Pesticide use dropped at Basking Ridge condo complex. 2 July 2015. <http://newjerseyhills.com/ bernardsville_news/news/pesticide-usedropped-at-basking-ridge-condo-complex/ article_ccd7ld7c-dfef-1 le l-be 8 a0019bb2963f4.html>.

Beyond Pesticides. 2008. New Jersey community adopts indoor IPM, parks go pesticide-free. 2 July 2015. <http://www. beyondpesticides.org/dailynewsblog/? $\mathrm{p}=347>$.

Beyond Pesticides. 2010. Maine towns restrict lawn chemicals. 2 July 2015. <http://www.beyondpesticides.org/ dailynewsblog/?p=4027>.

Beyond Pesticides. 2012a. State lawn pesticide notification laws. 2 July 2015. <https://www.google.com/search? $\mathrm{q}=$ state +lawn+notification \&ie $=u t f-$ $8 \&$ oe $=$ utf $-8 \& a q=t \& r l s=$ org. mozilla: en US:official\&client=firefox-a $>$.

Beyond Pesticides. 2012b. Ohio's Cuyahoga County bans most toxic pesticide use on county property. 2 July 2015. <http://www.beyondpesticides.org/ dailynewsblog/?p=7255>.

Blubaugh, C.K., V.A. Caceres, I. Kaplan, J. Larson, C.S. Sadof, and D.S. Richmond. 2011. Ground beetle (Coleoptera: Carabidae) phenology, diversity, and response to weed cover in a turfgrass ecosystem. Environ. Entomol. 40:1093-1101.

Boardman, J. 2012. Do-over in Durango: Western town goes organic after all. 2 July 2015. <http://www.safelawns.org/ blog/2012/09/do-over-in-durangowestern-town-goes-organic-after-all $/>$.

Bormann, F.H., D. Balmori, G.T. Geballe, and L. Vernegaard. 1993. Redesigning the American Lawn. Yale Press, New Haven, CT.

Bragg, M. 2012. Cape towns test chemfree property care. 2 July 2015 . <http:// www.capecodonline.com/apps/pbcs. dll/article?AID=/20120402/NEWS $/>$.

Braman, S.K. and R.F. Pendley. 1993. Relative and seasonal abundance of beneficial arthropods in centipede grass as influenced by management practices. J. Econ. Entomol. 86:494-504.

Braman, S.K., R.R. Duncan, and M.C. Engelke. 2000a. Evaluation of turfgrasses for resistance to fall armyworms (Lepidoptera: Noctuidae). HortScience 35:1268-1270.

Braman, S.K., R.R. Duncan, and M.C. Engelke. 2000b. Evaluation of turfgrasses for resistance to mole crickets (Orthoptera: Gryllidae). HortScience 35:665-668.

Braman, S.K., A.F. Pendley, and W. Corely. 2002. Influences of commercially available wildflower mixes on beneficial arthropod abundance and predation in turfgrass. Environ. Entomol. 31:564-572.

Braman, S.K., R.R. Duncan, W.W. Hanna, and M.C. Engelke. 2003. Arthropod predator occurrence and performance of Geocoris uliginosus (Say) on pest-resistant and susceptible turfgrasses. Environ. Entomol. 32:907-914.

Braman, S.K., R.R. Duncan, W.W. Hanna, and M.C. Engelke. 2004. Turfgrass species and cultivar influences on survival and parasitism of fall armyworm. J. Econ. Entomol. 97:1993-1998.

Bruneau, A.H. 1997. Organic lawn care: A guide to lawn maintenance and pest management for North Carolina. North Carolina Coop. Ext. Bull. 562.

Byrne, L.B. 2005. Of looks, laws, and lawns: How human aesthetic preferences influence landscape management, public policies and urban ecosystems. Proc. Emerging Issues Along Urban/Rural Interfaces Linking. Sci. Soc. 1:42-46.

Caceres, V., C.A. Bigelow, and D.S. Richmond. 2010. Aesthetic and economic impacts associated with four different coolseason lawn fertility and pesticide programs. HortTechnology 20:418-426.

Capone, L. 2002. Marblehead turning green without toxics. 2 July 2015. 
$<$ http://home.comcast.net/ little. sarah/GlobeMarbleheadsal.htm>.

Chamberlin, T. 2012. In the weeds: City council hears first round of organic land management debate. 2 July 2015. <http:// durangotelegraph.com/index.cfm/ archives/2012/Aug.-09-2012/news/ in-the-weeds $/>$.

Chicago Park District. 2011. Chicago park district continues to limit use of pesticides in parks. 2 July 2015 . <http:// www.chicagoparkdistrict.com/parkdistrict-continues-to-limit-use-ofpesticides-in-parks $/>$.

Christie, M. 2010. Private property pesticide by-laws in Canada: Population statistics by municipality. 2 July 2015 . <www. flora.org/healthyottawa/BylawList.pdf>.

City Council of Cuyahoga County, OH. 2011. Ordinance No. O2011-0047. 2 July 2015. <http://www.google.com/url? $\mathrm{sa}=\mathrm{t} \& \mathrm{rct}=\mathrm{j} \& \mathrm{q}=\& \mathrm{esrc}=\mathrm{s} \&$ source $=\mathrm{web} \&$ $\mathrm{cd}=1$ \&ved $=$ CDMQFjAA\&url=http $\% 3 \mathrm{~A} \%$ $2 \mathrm{~F} \% 2 \mathrm{Fw} w \mathrm{w}$.beyondpesticides.org $\%$ 2 Flawn $\% 2$ Factivist $\% 2$ Fdocuments $\%$ 2FCuyahogaCoOrdinance.pdf\&ei $=$ QsmfUMTbAZGk8QSblYBw\&usg= AFQjCNECf8ae_lsIKqHfZWZOrtNA8V _ wBQ\&sig2=_W-v_h28GQtRnATsfHWvag > .

City of Durango, CO. 1986. Code of ordinances: Article VII-Initiative, referendum, and recall. 2 July 2015 . <http:// library.municode.com/index.aspx? clientId=11771>

City of Durango, CO. 2012. Organically managed parks ordinance. 2 July 2015. <http:// www.google.com/url?sa $=$ t\&rct $=j \& q=\&$ esrc $=$ s\&source $=$ web\&cd $=4 \& v e d=0$ CEQQFjAD\& url $=$ http $\% 3 \mathrm{~A} \% 2 \mathrm{~F} \% 2 \mathrm{Fwww}$.beyondpesticides. org $\% 2$ Fdocuments $\% 2$ FDurango $\%$ 2520Proposed $\% 2520$ Organic\%2520Parks\% 2520 Ordinance.pdf\&ei=sISpUP7zG4SQ 9QSTIIDoDQ\&usg=AFQjCNEI0DGqer 4rp9NdjLTX56cXWWm7Vw\&sig2= cJsnu2RjcrMQMLlL8ejZrQ>.

Enumclaw Courier Herald. 2012. Parks managers from around King County working hard to reduce pesticide use. 2 July 2015. <http://www.courierherald. $\mathrm{com} /$ news/165007736.html>.

Frank, S. and P.M. Shrewsbury. 2004. Effect of conservation strips on the abundance and distribution of natural enemies and predation of Agrotis ipsilon (Lepidoptera: Noctuidae) on golf course fairways. Environ. Entomol. 33:1662-1672.

Government of Nova Scotia. 2011. Nonessential pesticides control act. 2 July 2015. <http://www.gov.ns.ca/nse/pests/ non-essential.pesticides.asp $>$.

Grey, G.W. and F.J. Deneke. 1986. Urban forestry. Wiley, New York, NY.
Greenbelt City Council. 2012. Agenda comments. 2 July 2015. <http://www. greenbeltmd.gov $/>$.

Held, D.W. 2005. Occurrence of Larra biocolor (Hymenoptera: Sphecidae), ectoparasite of mole crickets (Scapteriscus sp.) in coastal Mississippi. Fla. Entomol. $88: 327-328$

Held, D.W. and D.A. Potter. 2012. Prospects for managing turfgrass pests with reduced chemical inputs. Annu. Rev. Entomol. 54:329-354.

Hjertaas, P. 2007. Pesticide issues in Saskatchewan: A primer. Canadian Centre for Policy Alternatives: Saskatchewan notes 6 (2):1-4. 2 July 2015. <http://www. policy.ca/sites/default/files/uploads / publications/Saskatchewan_Pubs/2007/ sasknotes6_2_pesticides_primer.pdf $>$.

Henderson, S.P., N.H. Perkins, and M. Nelischer. 1998. Residential lawn alternatives: A study of their distribution, form and structure. Landscape Urban Plan. 42:135-145.

Jenkins, V.S. 1994. The lawn: A history of an American obsession. Smithsonian, Washington, DC.

Joseph, S.V. and S.K. Braman. 2009. Influence of plant parameters on occurrence and abundance of arthropods in residential turfgrass. J. Econ. Entomol. 102:1116-1122.

Joseph, S.V. and S.K. Braman. 2011. Occurrence of hymenopteran parasitoids in residential turfgrass in central Georgia. J. Entomol. Sci. 46:112-123.

Landis, D.A., S.D. Wratten, and G.M. Gurr. 2000. Habitat management to conserve natural enemies of arthropod pests in agriculture. Annu. Rev. Entomol. 45:175-201.

Langellotto, G.A. and R.F. Denno. 2004. Responses of invertebrate natural enemies to complex-structured habitats: A metaanalytical synthesis. Oecologia 139:14971503.

Marino, P.C. and D.A. Landis. 1996. Effect of landscape structure on parasitoid diversity and parasitism in agroecosystems. Ecol. Appl. 6:276-284.

Menalled, F., P. Marino, S. Gage, and D Landis. 1999. Does agricultural landscape structure affect parasitism and parasitoid diversity? Ecol. Appl. 9:634-641.

Milesi, C., S.W. Running, C.D. Elvidge, J.B. Dietz, B.T. Tuttle, and R.R. Nemani. 2005. Mapping and modeling the biogeochemical cycling of turf grasses in the United States. Environ. Mgt. 36:426-438.

Morris, A. 2011. A work in progress. 2 July 2015. <http://www.superintendentmagazine. com>.
Morris, J. and J. Bagby. 2008. Measuring environmental value for natural lawn and garden care practices. Intl. J. Life Cycle Assessment 13:226-234.

New Jersey Department of Environmental Protection. 2004. New Jersey school integrated pest management (IPM) program: Laws and regulations. 2 July 2015. <http://www.nj.gov/dep/enforcement/ pcp/pcp-ipm.htm>.

Pennington, B. 2010. Exclusive golf course is organic, so weeds get in. 2 July 2015. <http://www.nytimes.com/ $2010 / 08 / 17 /$ sports/golf/17vineyard. html?_r=l\&=all>.

Pedigo, L.P. and M.E. Rice. 2006. Entomology and pest management. 5th ed. Pearson, Upper Saddle River, NJ.

Pimental, D., P. Hepperly, J. Hanson, D. Douds, and R. Seidel. 2005. Environmental, energetic, and economic comparisons of organic and conventional farming systems. Bioscience 55:573-582.

Potter, D.A. and S.K. Braman. 1991. Ecology and management of turfgrass insects. Annu. Rev. Entomol. 36:383-406.

Potter, D.A. 1993. Pesticide and fertilizer effects on beneficial invertebrates and consequences for thatch degradation and pest outbreaks in turfgrass, p. 331-343. In: K.D. Racke and A.R. Leslie (eds.). Pesticides and urban environments. Amer. Chem. Soc., Washington, DC.

Pralle, S. 2006a. The mouse that roared: Agenda setting in Canadian pesticide politics. Policy Stud. J. 34:171-196.

Pralle, S. 2006b. Timing and sequence in agenda setting and policy change: A comparative study of lawn care pesticide politics in Canada and the U.S. J. Eur. Public Policy 13:987-1005.

Province of Ontario. 2009. Pesticides Act. 2 July 2015. <http://www.e-laws.gov. on.ca/html/regs/english/elaws_regs_ 090063_e.htm\#BK19>.

Province of Quebec. 2012. Pesticides Management Code. 2 July 2015. <http:// www2.gouv.qc.ca/dynamicSearch/ telecharge. php? type $=3 \&$ file $=/$ P_9_3 $/$ P9_3Rl_A.HTM>

Quisenberry, S.S. 1990. Plant resistance to insects and mites in forage and turf grasses. Fla. Entomol. 73:411-421.

Raupp, M.J., P.M. Shrewsbury, and D.A. Herms. 2010. Urban systems often involve less frequently disturbed perennial plantings and may have higher plant diversity than natural areas in some cases. Annu. Rev. Entomol. 55:19-38.

Raver, A. 2009. The grass is greener at Harvard. 2 July 2015. <http://nytimes. 
com/2009/09/24/garden/24garden. html? pagewanted $=$ all $>$.

Reinert, J.A., M.C. Engelke, and J.C. Read. 2004. Host resistance to insects and mites-a major IPM strategy in turfgrass culture. Acta Hort. 661:463-486.

Riddle, L. 2011. Sustainable land care policy. 2 July 2015. <http://www.google.com/ url? $\mathrm{sa}=\mathrm{t} \& \mathrm{rct}=\mathrm{j} \& \mathrm{q}=\&$ esrc $=\mathrm{s} \&$ source $=$ web $\&$ $\mathrm{cd}=1$ \&ved=0CE8QFjAA\&url=http $\% 3 \mathrm{~A} \%$ $2 \mathrm{~F} \% 2 \mathrm{Fwww}$.greenbeltmd.gov\%2 Fcity government $\% 2$ Fagenda_packet_1_9_12\% 2Fsustainable_land_care_policy.pdf\&ei= LdeZUPWvM43g8ATT5oDACg\&usg= AFQjCNHXYIfmLxvdSructmbafllLwSPfQ\& sig2=I09wMtxp0okrv6KBFX4mcQ $>$.

Robbins, P., A. Polderman, and T. Birkenholtz. 2001. Lawns and toxins: An ecology of the city. Cities Intl. J. Urban Policy Planning 18:369-380.

Robbins, P. and J. Sharp. 2003a. Producing and consuming chemicals: The moral economy of the American lawn. Econ. Geogr. 79:425-451.

Robbins, P. and J. Sharp. 2003b. The lawn-chemical economy and its discontents. Antipode 35:955-979.

Shortman, S.L., S.K. Braman, R.R. Duncan, W.W. Hanna, and M.C. Engelke. 2002. Evaluation of turfgrass species and varieties for potential resistance to twolined spittlebug, Prosapie bicincta (Say) (Homoptera: Cercopidae). J. Econ. Entomol. 95:478486.

Shrewsbury, P.M. and M.J. Raupp. 2000. Evaluation of components of vegetational texture for predicting azalea lace bug, Stephanities pyrioides (Heteroptera: Tingidae), abundance in managed landscapes. Popul. Ecol. 29:919-925.

Shrewsbury, P.M. and M.J. Raupp. 2006. Do top-down or bottom-up forces determine Stephanities pyrioides abundance in urban landscapes? Ecol. Appl. 16:262272.

Smith, V. 2011. Organic: The old college try. 2 July 2015. <http://philly.com/ 2011-10-21/news/30305536_1_ organic-lawn-organic-care-compost $>$.

Suzuki, D. and F. Moola. 2009. Ontario joins the movement to make lawns and gardens green. 2 July 2015. <http://www. davidsuzuki.org/blogs/science-matters/ 2009/03/ontario-joins-the-movement-tomake-lawns-and-gardens-green $/>$.

Tallamy, D. 2007. Bringing nature home: How you can sustain wildlife with native plants. Timber Press, Portland, OR.

Theis, C., I. Steffan-Dewenter, and T. Tscharntke. 2003. Effects of landscape context on herbivory and parasitism at different spatial scales. Oikos 101:18-25.

Town of Camden, ME. 2008. Pest management policy. 2 July 2015. <http://www.google.com/url?sa=t\&rct= $j \& q=\&$ esrc $=s \&$ source $=$ web \& $c d=2 \& v e d=$ 0CDgQFjAB\&url=http $\% 3 \mathrm{~A} \% 2 \mathrm{~F} \% 2 \mathrm{Fwww}$. beyondpesticides.org $\% 2 \mathrm{Fdocuments} \%$ 2FCamdenPolicy.pdf\&ei=xJmpUOqqEYy9gSqxIDgCA\&usg=AFQjCNFu-nky85A7 wxqKuS9mgUSVQoZOlQ\&sig2=7Bff3j DOTChYLUGFHyrfGw>.

Town of Carrboro, NC, Department of Public Works. 1999. Least toxic integrated pest management policy. 2 July 2015. <http://www.ci.carrboro.nc.us/PW/ipm. htm\#>.

Town of Marblehead, ME. 2001. Organic pest management policy for turf and landscape. 2 July 2015. <http://www.google.com/ url? sa $=t \& r c t=j \& q=\&$ es $r c=s \&$ source $=$ web \&cd =3\&ved=0CEAQFjAC\&url= http $\% 3 \mathrm{~A} \% 2 \mathrm{~F} \% 2 \mathrm{Fsustainability.tufts.}$ edu $\% 2$ Fwp-content $\% 2$ Fuploads $\%$ 2FMarbleheadpestmanagementpolicy.pdf\& ei=RXi7UKj0Mobc8wSJ5oD4BQ\&usg= AFQjCNGQf6 KBj NRr7kFvbZ_ fyZO5ahWnzg\&sig2=8dX5DdVEZCbwo-hjPy7-A>

Tukey, P. 2007. The organic lawn care manual: A natural, low-maintenance system for a beautiful, safe lawn. Storey Publ., Boston, MA.

Tukey, P. 2012a. America's most progressive campus: Colorado goes truly green on its lawns. 2 July 2015. <http://www. safelawns.org/blog/2012/10/americasmost-progressive-campus-colorado-goestruly-green-on-its-lawns/>.

Tukey, P. 2012b. University of Arizona embraces organic lawn care. 2 July 2015. $<$ http://www.safelawns.org/blog/ $2012 / 08 /$ university-of-arizonaembraces-organic-lawn-care/ $>$.

U.S. Census Bureau. 2012. Growth in urban population outpaces rest of nation, Census Bureau reports. 2 July 2015. <http://www. census.gov/newsroom/releases/archives/ 2010_census/cbl2-50.html.>.

U.S. Environmental Protection Agency. n.d. Integrated pest management in schools: Protecting children in schools from pests and pesticides. 2 July 2015. <http://www. epa.gov/opp00001/ipm/>.

U.S. Environmental Protection Agency. 2012. Pesticides: Topical and chemical fact sheets. 2 July 2015 . <http://epa. gov/opp00001/factsheets/ipm.htm>.

U.S. Geological Survey. 1999. The quality of our nation's waters-nutrients and pesticides. U.S. Geological Survey Circ. 1225 .

U.S. Department of Agriculture. 1995. Organic production/organic food: Information access tools. 2 July 2015. <http://www.nal.usda.gov/afsic/pubs/ ofp/ofp.shtml>.

Vickers, A. 2006. New directions in lawn and landscape water conservation. Amer. Water Works Assn. 98:56-61.

Village of New Paltz Board of Trustees. 2008. Healthy turf and landscape policy. 2 July 2015 . < http://www. beyondpesticides.org/lawn/activist/ NewPaltzNYfinalpolicy.pdf $>$.

Winnipeg Free Press. 2012. Manitoba lobbied today to end cosmetic pesticides. 2 July 2015. <http://www.winnipegfreepress. com/breakingnews/Manitoba-lobbiedtoday-to-end-cosmetic-pesticides170975031.html>. 